\title{
Tour Production Costs
}

\section{Ralf Buckley}

International Chair in Ecotourism Research Griffith, University, Parklands Drive, Gold Coast, Queensland 4222, Australia.

Email: r.buckley@griffith.edu.au

Profitability depends on production costs as much as it depends on sales revenue. Information on production costs is therefore critical in the analysis of competitive commercial enterprises in all industry sectors. The dynamics of any industry sector, under either market or policy changes, depend on the relative production costs of its individual enterprises. Empirical data on production costs are sparse, however, because of commercial sensitivity. Stock exchanges show share prices, and annual financial reports show aggregate income and outgoings, but unit production costs are treated as confidential. Here, therefore, I argue for greater effort in empirical studies on production costs in tourism, to complement the existing body of theoretical research. In particular, I suggest that empirical information on production costs is prerequisite to analyze the value contributed by agents and intermediaries in tourism distribution systems. As an initial case study, I present data from six similar small-group international package tours in the nature and adventure subsector.

In tourism, the most typical product design is a package that assembles a complex set of goods and services by purchasing and linking localized or specialized transport, accommodation, and activity subproducts. Theoretical aspects of the assembly, marketing, costs, pricing, and operation of package tours have been studied extensively (Assaf, Barros, and Dieke 2011; Chen, Mak, and Guo 2011; Choi et al. 2012; Enoch 1996; Gursey and McClearly 2004; Mosedale 2006; Reimer 1990; Sheldon 1986; Sheldon and Mak 1987; Sigala 2010, 2012; Wong and Liu 2011; Wong and McKercher 2012; Zillinger, Jonasson, and Adolfsson 2012). Most of these approaches are applications of management accounting theory (Brignall et al. 1991; Mattimoe and Seal 2011). Their focus, however, is on theory rather than empirical data.

In the nature and adventure tourism subsector, many products are small-group guided packages including accommodation, catering, transport, activities, and ancillaries (Buckley 2007; Reimer 1990; Zillinger, Jonasson, and Adolfsson 2012). Retail operators assemble components, negotiate rates, employ guides, and market and run the tours. They publish 
itineraries with enough information for clients or competitors to identify and purchase the components themselves, using online marketing, booking, and sales systems (Anckar and Walden 2001; Boffa and Succurro 2012; Chen and Schwartz 2006; Klein, Kohne, and Oomi 2004; Llach et al. 2012; Sparks and Browning 2011). It is also simple to estimate office overheads.

What remain hidden are the labor costs of the tour assembly process, an essential component of tour production costs. These derive from the skilled staff time needed to design, negotiate, package, market, and operate each tour. There are apparently no published empirical data on these time costs of tour assembly (Dwyer, Forsyth, and Dwyer 2010; Stabler, Papatheodrou, and Sinclair 2010). The closest approach is that of Sheldon (1986), based on rack-rate prices derived from marketing materials. These, however, ignore discounts, commissions, and profits and yield only approximate estimates of labor costs.

The most reliable way to obtain empirical data is to actually run tours, with real-life investment of time, negotiation and purchase of subcomponents, marketing and sales, guiding, and operations. Here I present results for six such tours, run between 2003 and 2012 in New Zealand, Papua New Guinea, Nepal, Ecuador, Finland, and the United States. They ranged from 10 to 25 days in-country, with group sizes of 12-25. Activities included diving, seakayaking, whitewater rafting, wildlife watching, elephant riding, and trekking and backcountry camping at up to $5000 \mathrm{~m}$. I used prior industry experience to obtain discounts of up to $50 \%$, and to allocate time efficiently. I recorded cost and time components through invoices, diaries, and email records. For four of six tours, I also made prior pilot visits, not included in cost calculations here since for commercial enterprises those costs are amortized over multiple repeat tours.

Table 1 shows the number of paying participants $N$ per tour; total hours $H$ in assembling, marketing, and leading each tour; aggregate per capita cost $C$ of purchased subcomponents; and per capita retail prices $P$ for closest equivalent commercial package tours available currently. All costs and prices are expressed in 2012 U.S. dollars, adjusted using historical inflation and current forex rates. Figures for $N$ and $C$ are known precisely, and $H$ values are accurate to within $\pm 5 \%-10 \%$. $C$ and $P$ exclude international travel, since clients typically arrive from different countries of origin on a wide range of different flight itineraries and airfare structures. Prices $\mathrm{P}$ are for inclusive tours with experienced colingual guides. 
This seems to be the first published study to record time and cost components systematically from real-life tours. From 300 to 400 hours of skilled labor are required to assemble, market, and operate each of these tours. Per capita costs $C$ of purchased subcomponents are not correlated with per capita retail prices $P$. Values of $C$ are not dissimilar in developed and developing nations, but $P$ are higher in the former (Table 1). Ratios $C / P$ range from $25 \%$ to $65 \%$, and these variations merit further research. Salaries, overheads and insurance, and commissions for tours sold through agents as well as online, may differ between nations.

Tourists can save money by assembling their own groups and itineraries. If groups pick one person to assemble and lead, and there are no office overheads, they could pay the leader up to $\$ 77-\$ 125 /$ hour, calculated from Table 1 as $S=N(P-C) / H$. Wealthy clients purchasing upmarket tours generally do use expert travel agents or tour designers, whereas less wealthy clients often assemble their own groups and itineraries, and book online. The difference $P-C$, however, covers commercial overheads, commissions, and profit as well as labor. In addition, reputable tour operators provide quality assurance, expert knowledge, and risk management. High $P$-to- $C$ ratios indicate that tourists value these intangibles, providing a niche for intermediaries in traditional travel distribution systems. Research to quantify these intangible values provides a promising opportunity. Such research, however, first requires extensive empirical data on tour production costs. This is a gap that deserves attention. 


\section{References}

Anckar, B., and P. Walden. (2001). "Self-Booking of High and Low Complexity Travel Products: Exploratory Findings." Information Technology and Tourism, 4:151-65.

Assaf, A. G., C. P. Barros, and P. U. C. Dieke. (2011). "Portuguese Tour Operators: A Fight for Survival.” Journal of Air Transport Management, 17:155-57.

Boffa, F., and M. Succurro. (2012). "The Impact of Search Cost Reduction on Seasonality." Annals of Tourism Research, 39:1176-98.

Brignall, T. J., L. Fitzgerald, R. Johnston, and R. Silvestro. (1991). "Product Costing in Service Organisations.” Management Accounting Research, 2:227-48.

Buckley, R. C. (2007). “Adventure Tourism Products: Price, Duration, Skill, Remoteness.” Tourism Management, 28:1428-33.

Chen, C. C., and Z. Schwartz. (2006). "The Importance of Information Asymmetry in Customers' Booking Decisions.” Cornell Hotel and Restaurant Quarterly, 47:272-85.

Chen, Y., B. Mak, and Y. Z. Guo. (2011). “'Zero-Fare' Group Tours in China: An Analytic Framework." Journal of China Tourism Research, 7:425-44.

Choi, S., X. R. Lehto, A. M. Morrison, and S. C. Jang. (2012). "Structure of Travel Planning Processes and Information Use Patterns.” Journal of Travel Research, 51:26-40.

Dwyer, L., P. Forsyth, and W. Dwyer. (2010). Tourism Economics and Policy. Bristol: Channel View.

Enoch, Y. (1996). "Contents of Tour Packages: A Cross-Cultural Comparison." Annals of Tourism Research, 23:599-616.

Gursey, D., and K. W. McClearly. (2004). “An Integrative Model of Tourists' Information Search Behaviour." Annals of Tourism Research, 31:353-73.

Klein, S., F. Kohne, and A. Oomi. (2004). "Barriers to Online Booking of Scheduled Airline Tickets." Journal of Travel and Tourism Marketing, 17:27-39.

Llach, J., F. Marimon, M. M. Alonso-Almeida, and M. Bernardo. (2012). "Determinants of Online Booking Loyalties for the Purchasing of Airline Tickets." Tourism Management, 35:23-31.

Mattimoe, R., and W. Seal. (2011). "Pricing in a Service Sector Context: Accounting and Marketing Logics in the Hotel Industry." European Accounting Review, 20:355-88.

Mosedale, J. (2006). "Tourism Commodity Chains: Market Entry and Its Effect on St Lucia." Current Issues in Tourism, 9:436-58.

Reimer, G. D. (1990). "Packaging Dreams: Canadian Tour Operators at Work." Annals of Tourism Research, 17:501-12. 
Sheldon, P. (1986). "The Tour Operator Industry: An Analysis.” Annals of Tourism Research, 13:349-65.

Sheldon, P., and J. Mak. (1987). "The Demand for Package Tours: A Mode Choice Model." Journal of Travel Research, 25:13-17.

Sigala, M. (2010). "Measuring Customer Value in Online Collaborative Trip Planning Processes." Marketing Intelligence and Planning, 28:418-43.

Sigala, M. (2012). "The Impact of Geocollaborative Portals on Group Decision Making for Trip Planning.” European Journal of Information Systems, 21:404-26.

Sparks, B., and V. Browning. (2011). "The Impact of Online Reviews on Hotel Booking Intentions and the Perception of Trust." Tourism Management, 32:1310-23.

Stabler, M., A. Papatheodrou, and M. T. Sinclair. (2010). The Economics of Tourism, 2nd edition. Oxford: Routledge.

Wong, C. K. S., and F. C. G. Liu. (2011). "A Study of Pre-trip Use of Travel Guidebooks by Leisure Travellers.” Tourism Management, 32:616-28.

Wong, C. U. I., and B. McKercher. (2012). "Day Tour Itineraries: Searching for the Balance between Commercial Needs and Experiential Desires." Tourism Management, 33:1360-72.

Zillinger, M., M. Jonasson, and P. Adolfsson. (2012). "Guided Tours and Tourism." Scandinavian Journal of Hospitality and Tourism, 12:1-7.

\section{Author Biography}

Ralf Buckley holds the International Chair in Ecotourism Research at Griffith University, Australia. His principal current interests are in adventure tourism and conservation tourism. During 2014 he is also Distinguished International Visiting Professor at the Chinese Academy of Sciences. 
Table 1. Tour Statistics and Cost Components

\begin{tabular}{cccccc} 
Year & $\mathbf{I n} \boldsymbol{\dagger}$ & $\mathbf{N}$ & $\mathbf{H}$ & $\mathbf{C}$ & $\mathbf{P}$ \\
\hline 2003 & $\mathrm{NZ}$ & 17 & 400 & 1,810 & 4,800 \\
2005 & $\mathrm{PG}$ & 23 & 400 & 1,720 & 3,050 \\
2007 & $\mathrm{NP}$ & 25 & 300 & 1,620 & 2,500 \\
2009 & EC & 13 & 400 & 1,515 & 4,015 \\
2012 & FI & 12 & 350 & 1,400 & 4,900 \\
2012 & US & 12 & 350 & 1,250 & 5,000 \\
\hline
\end{tabular}

Note: $H=$ hours invested by leader, rounded to nearest $10 ; C=$ total in-country purchased cost components, per person; $P=$ retail price of closest equivalent commercial tour package, per person; ( $C$ and $P$ are in 2012 U.S. dollars); $N=$ number of clients. NZ, New Zealand; PG, Papua New Guinea; NP, Nepal; EC, Ecuador; FI, Finland; US, USA. 